\title{
Civil Recovery from Delinquent Directors
}

\author{
Richard Williams*
}

\begin{abstract}
This paper analyses the likely impact of new civil recovery powers that allow the State to launch personal liability proceedings against directors of failed companies. The paper presents the results of an analysis of the incidence of personal bankruptcy in a sample of over 450 wrongdoing directors. This analysis suggests that directors implicated in serious wrongdoing are more likely than the norm to be declared bankrupt by a factor of some 19,000. The paper presents this and other analysis to argue that new civil recovery powers are unlikely to result in a significant upswing in civil recovery for creditors of failed companies.
\end{abstract}

\section{A. INTRODUCTION.}

In a reaffirmation of UK policy makers' focus on ex-post ${ }^{1}$ sanctions to protect creditors from the supposed evils of limited liability, the UK Government has proposed significant new powers allowing the State to pursue civil compensation claims against wrongdoing directors. The objective of this reform is to increase the amount of financial compensation obtained for creditors of insolvent companies. The new powers will be integrated into the UK's already highly developed director disqualification regime to provide that directors who are disqualified from acting in the management of companies may be made liable to compensate creditors who have suffered loss as a result of their misconduct, either by means of a contribution to the assets of insolvent firms, or by way of more direct payments to creditors. The powers are to be introduced alongside other measures to consolidate and expand the disqualification regime, such as allowing for the disqualification of 'shadow directors' implicated in unfit conduct and reforming statutory guidance as to the matters that may be taken into account in disqualification for unfitness cases. ${ }^{2}$

The new civil recovery powers were justified by the UK Department for Business, Innovation and Skills (BIS) as a necessary response to a 'market failure' in relationships between corporations and their creditors that is born out of creditors' inability to effectively manage risks created by limited liability. ${ }^{3}$ The same 'market failure' analysis, of course, underpins

\footnotetext{
*Hogan Lovells University Lecturer in Corporate Law, Christ's College, University of Cambridge.

${ }^{1}$ See generally R Kraakman and J Armour et al, The Anatomy of Corporate Law: A Comparative and Functional Approach, (Oxford: OUP, 2nd ed, 2009) 44-45.

${ }^{2}$ See Small Business, Enterprise and Employment Act 2015, ss 104 -116 and further Department for Business, Innovation and Skills, Transparency and Trust: Enhancing the Transparency of UK Company Ownership and Increasing Trust in UK Businesses (July 2013) 55-69 available at https://www.gov.uk/government/uploads/system/uploads/attachment_data/file/212079/bis-13-959transparency-and-trust-enhancing-the-transparency-of-uk-company-ownership-and-increaing-trust-inuk-business.pdf (last viewed 8 October 2014);Department for Business, Innovation and Skills, Transparency and Trust: Enhancing the Transparency of UK Company Ownership and Increasing Trust in UK Businesses: Government Response (April 2014) 52-59, available at https://www.gov.uk/government/uploads/system/uploads/attachment_data/file/304297/bis-14-672transparency-and-trust-consultation-response.pdf (last viewed 8 October 2014).

${ }^{3}$ Department for Business, Innovation and Skills, Small Business, Enterprise and Employment Bill: giving the Court and Secretary of State a Power to Make a Compensation Award against A Directors (BIS/14/932) 12 (available at:
} 
existing civil recovery provisions in UK corporate law, such as the wrongful trading rule in section 214 of the Insolvency Act 1986 (IA 1986) ${ }^{4}$ and the 'misfeasance' rule in section 212 of the same enactment, as well as the core director disqualification regime. However, whilst the new civil recovery powers seek to address an old problem, the regulatory solution offered is a novel one. Existing civil recovery powers, such as those in sections 214 and 212 IA 1986, place the task of civil recovery in the hands of liquidators ${ }^{5}$ of insolvent companies, who initiate recovery proceedings on behalf of the insolvent estate as an integral part of their role in gathering in the available assets of insolvent companies and distributing the creditors in accordance with the statutory scheme. The new powers, in contrast, place the task of civil recovery in the hands of the State, more specifically the Secretary of State, who is, of course, a public official with no direct role in administering the affairs of insolvent companies. As such, the new powers have the potential to significantly increase the importance of 'public' regulatory proceedings in corporate insolvency.

Reliance on the 'market failure' case for enhanced regulation to protect creditors via the new powers gives us two important insights into the mind-set of UK policy makers. First, and most obviously, it affirms policy makers' belief that a significant 'market failure' affects corporate-creditor relationships such that regulatory intervention is justified to 'protect creditors'. Second, it shows that policy makers do not regard existing powers of civil recovery as sufficiently effective in remedying that failure. New rules to grant civil recovery powers to the State would simply not be justified if existing ('private') powers of civil recovery were seen to be sufficiently effective in correcting the 'failed' market.

This paper argues that the new civil recovery powers are unlikely to yield a significant increase in "financial redress to creditors" of failed companies. The paper presents three related arguments to support this contention, namely, (1) that the policy case for the new powers is uncertain, (2) that high levels of bankruptcy amongst directors responsible for corporate misconduct significantly restricts the scope for the application of civil recovery powers, and (3) that, in the specific context of disqualification, relatively few cases concern misconduct that causes ascertainable loss for creditors. As such, the paper begins by outlining the proposed new powers in detail and critically evaluates the 'market failure' analysis that is offered as justification for expanding the role of the state into civil recovery. The paper notes that there is little hard evidence of the extent to which market transactions leave creditors unduly exposed to harmful effects from limited liability and, as such, questions the extent to which new regulation is in fact necessary to protect creditors. In this context the paper also notes a dearth of evidence to suggest that existing, liquidator based, powers of civil recovery

https://www.gov.uk/government/uploads/system/uploads/attachment_data/file/322856/bis_14_932_giv ing the court and SoS a power to make a compensatory_award_against_a director.pdf

${ }^{4}$ See eg D Prentice, 'Corporate Personality, Limited Liability and the Protection of Creditors' in R Grantham and C Rickett (eds) Corporate Personality in the $20^{\text {th }}$ Century, (Oxford: Hart, 1998) 109110; A Keay 'Wrongful Trading and the Liability of Company Directors: A Theoretical Perspective' [1996] Legal Studies 431, 434; and further R Williams, 'What Can we Expect to Gain from Reforming the Insolvent Trading Remedy?’ (2015) 78 Modern Law Review 55, 58-59.

${ }^{5}$ Recovery powers in respect of wrongful trading are also granted to administrators of companies that enter insolvent administration by s 117 of the Small Business, Enterprise and Employment Act 2015.

${ }^{6}$ Department for Business, Innovation and Skills, Transparency and Trust: Enhancing the

Transparency of UK Company Ownership and Increasing Trust in UK Businesses (July 2013), 70, available at https://www.gov.uk/government/uploads/system/uploads/attachment_data/file/212079/bis13-959-transparency-and-trust-enhancing-the-transparency-of-uk-company-ownership-and-increaingtrust-in-uk-business.pdf (last viewed 8 October 2014); Department for Business, Innovation and Skills, Transparency and Trust: Enhancing the Transparency of UK Company Ownership and Increasing Trust in UK Businesses: Government Response (April 2014), 64, available at https://www.gov.uk/government/uploads/system/uploads/attachment data/file/304297/bis-14-672transparency-and-trust-consultation-response.pdf (last viewed 8 October 2014). 
have underperformed relative to the potential pool of civil recovery cases. The second section of the paper presents an empirical study of the incidence of personal bankruptcy in a sample of 450 directors disqualified for unfit conduct that was conducted in order to assess the likely impact of new civil recovery powers. This research suggests that high bankruptcy rates amongst those responsible for serious misconduct mean that potential benefits of the new system are limited and, by extension, that the scope for application of existing civil recovery powers is more limited than may be appreciated. The next section of the paper analyses evidence of the misconduct committed in disqualification cases and shows that only a minority of disqualification cases are likely to be suitable for civil recovery proceedings. In this context the paper presents further evidence which suggests that directors responsible for conduct that inflicts financial harm on creditors are more likely to be declared bankrupt than are directors responsible for other forms of misconduct. The final section of the paper discusses the likely deterrent impact the new powers and concerns about the procedural fairness of a key plank of the reforms.

\section{B. THE NEW POWERS: COMPENSATION ORDERS AND UNDERTAKINGS.}

Powers to allow civil recovery from disqualified directors were first proposed by the UK Government in its 2013 "Transparency and Trust", discussion paper. The 'Transparency' agenda covered in a number of different areas of corporate law and was broadly motivated by a post-crisis desire to increase trust in UK business through enhanced regulation in certain key areas, ${ }^{8}$ of which introducing new civil recovery powers against disqualified directors was one. Legislation was brought forward in 2014 and received Royal Assent in March 2015 as part of the Small Business, Enterprise and Employment Act 2015 (SBEE). When fully implemented the SBEE will insert a new section 15A in to the Company Directors Disqualification Act 1986 (CDDA) giving courts the power to make a civil 'compensation order' against disqualified individuals following an application to the court for such an order by the Secretary of State. The new section sets out two conditions that must be met before a compensation order may be granted, namely, that (a) that the person to whom the application relates is subject to a current disqualification order or undertaking under the CDDA and (b) that the conduct for which the person was disqualified "has caused loss to one or more creditors" of an insolvent company of which the disqualified individual was a director (s $15 \mathrm{~A}(3))$. An 'insolvent company' for the purposes of section $15 \mathrm{~A}(3)(\mathrm{b})$ is defined as a company that is or has been insolvent on the basis that it either entered liquidation, administration or administrative receivership at a time when its assets were insufficient for the payment of its debts and other liabilities (including the expenses of the winding up) ( $\mathrm{s}$ $15 \mathrm{~A}$ (4)). The Secretary of State is permitted to apply for a compensation order at any time up to two years after the date of the making of a disqualification order or the acceptance of a disqualification undertaking (s 15A(5)).

In keeping with the scheme of disqualification undertakings that has been in place since 2001, the new provision also permits the Secretary of State to accept a 'compensation undertaking' from a disqualified individual as an alternative to court proceedings for a compensation order. Again, following a model already well established in the CDDA, the criteria for obtaining a compensation undertaking mirror those applicable to compensation orders, but with the court replaced by the Secretary of State as the arbiter of those conditions. Section 15A(2) accordingly states that the Secretary of State may (but does not have to) accept a compensation undertaking from a individual where such an undertaking is offered and it "appears to the Secretary of State" that the conditions mentioned in section $15 \mathrm{~A}(3)$ are satisfied, namely that the individual has been disqualified under the CDDA and their conduct has 'caused loss to creditors'. As such, the provision creates a broad administrative

\footnotetext{
${ }^{7}$ Department for Business, Innovation and Skills, Transparency and Trust: Enhancing the Transparency of UK Company Ownership and Increasing Trust in UK Businesses (July 2013), n2.

${ }^{8}$ ibid, 'Forward by the Secretary of State', 3-4.
} 
jurisdiction over the section $15 \mathrm{~A}(3)$ criteria that is equal to, though separate from, that of the court - the Secretary of State may accept the offer a compensation undertaking where he thinks conditions are met not where he thinks the court would regard the relevant conditions as met.

In terms of substance, both compensation orders and compensation undertakings impose an obligation on the individual subject to the undertaking/order to pay an amount specified in the order/undertaking to either (a) the Secretary of State for the benefit of specified creditors, or a specified class of creditors or (b) as a general contribution to the assets of the company (ss $15 \mathrm{~B}(1)$ and (2)). In specifying the amount to be paid the court or the Secretary of State is required by section $15 \mathrm{~B}$ to 'have regard' to the amount of the loss caused by the director's misconduct, the nature of that conduct and whether the disqualified individual has made any other financial contribution in recompense for his or her conduct, whether voluntarily, under an obligation imposed by a statutory provision (eg s 212 IA 1986 or s 214 IA 1986) or otherwise. By virtue of section $15 \mathrm{~B}(5)$, sums payable under a compensation order or undertaking are made provable in the bankruptcy of the individual subject to the compensation obligation.

\section{C. 'MARKET FAILURE' AND THE CASE FOR THE NEW POWERS}

Civil recovery against wrongdoing directors has a substantial pedigree in UK corporate law as a remedy for abuse of limited liability. The Greene Committee Report of 1926, for example, expressed concern about increased risks for creditors of some limited liability entities from abusive behaviour ${ }^{9}$ and recommended the introduction of civil liability for fraudulent trading in response. A watershed in the use of civil recovery was, however, reached with the publication of the Cork Report ${ }^{10}$ in the early 1980s. Cork was, of course, the genius behind the expanded disqualification for unfitness regime ${ }^{11}$ implemented in $1985 / 1986,{ }^{12}$ but alongside this advocated a significant expansion in civil liability rules to enhance creditor protection, most notably through the introduction of the wrongful trading remedy ${ }^{13}$. In respect of both disqualification and wrongful trading the Cork Report presented a case for enhanced regulation that was based squarely on the notion that 'market failure' in relationships between creditors and corporations left the former exposed to perverse incentives created by limited liability. ${ }^{14}$ The analysis advanced by the Cork Committee was accepted by the UK government in its 1984 White Paper on insolvency law reform. ${ }^{15}$

Reliance on 'market failure' analysis places both disqualification and wrongful trading in the broad realm of 'public interest regulation" ${ }^{16}$ in the sense that both measures seek to remedy transaction cost and information asymmetry problems ${ }^{17}$ affecting corporate-creditor

\footnotetext{
${ }^{9}$ Company Law Amendment Committee (The Greene Committee), Cmd 2657 (1926), para 86.

${ }^{10}$ Insolvency Law and Practice: Report of the Review Committee, (Chairman, Sir Kenneth Cork), Cmnd 8558 (1982) (hereinafter 'Cork Report').

${ }^{11}$ Cork Report, ibid, ch 45.

${ }^{12}$ Insolvency Act 1985, ss 12-14; Company Directors Disqualification Act 1986 (consolidating existing and new disqualification provisions).

${ }^{13}$ Cork Report, $\mathrm{n}$ 9, ch 44.

${ }^{14}$ See eg Cork Report, ibid, paras 1739-1744. See further Williams, 'What can we expect to gain from Reforming the Insolvent Trading Remedy?' n 4; R Williams, Disqualification Undertakings: Law Policy and Practice (Bristol: Jordan Publishing, 2011) Ch 2.

${ }^{15}$ A Revised Framework for Insolvency Law, Cmnd 9175 (1984).

${ }^{16}$ See eg A Ogus, Regulation: Legal Form and Economic Theory (Oxford: Clarendon Press, 2004) 3-4 $\&$ Ch 3.

${ }^{17}$ See eg (in the context of wrongful trading) R Williams, 'Reforming the Insolvent Trading Remedy?' $\mathrm{n}$ 4. On information asymmetry problems facing creditors see generally, J Landers, 'A Unified Approach to Parent Subsidiary and Affiliate Questions in Bankruptcy' (1975) 42 University of Chicago Law Review 499; P Halpern, M Trebilcock and S Turnbull, 'An Economic Analysis of
} 
relationships for the 'public good'. However, the regulatory techniques adopted by each measure to fulfil the public interest goal are rather different. In disqualification of unfitness under sections $6 \& 8$ of the CDDA, the goal of "protecting the public and commercial world ${ }^{18}$ is advanced by means of a general prohibition on acting in the management of companies, with the Secretary of State, as a public official, charged with the task of bringing disqualification proceedings on the basis of an explicit public interest test. ${ }^{19}$ The wrongful trading remedy, by contrast, provides for direct civil recovery from delinquent directors with the power to bring recovery proceedings placed in the hands of liquidators, who act on behalf of the creditors of the insolvent firm ${ }^{20}$ in deciding whether to initiate proceedings against wrongdoing directors.

The case presented by the UK Government in making the case for the new civil recovery powers relies on the same notion of 'market failure' that was presented by Cork for the initial disqualification and wrongful trading measures, ${ }^{21}$ with BIS highlighting in particular the 'moral hazard' problem of directors who are insulated from downside financial risks by limited liability being more likely to engage in misconduct or take undue risks with corporate funds. ${ }^{22}$ However, whilst the case for the new powers rests on familiar arguments, they offer a solution that combines direct recovery for creditors (such as is provided by the existing wrongful trading rule) with the 'public regulatory' mechanisms of disqualification in that powers to launch civil recovery proceedings under the rules are placed in the hands of the Secretary of State, which in practice means the Insolvency Service division of the Department for Business.

\section{Has the Market failed?}

Policy makers' central claim that creditors are exposed to increased risk of directors' misconduct because of the insulating effect of limited liability has, of course, widespread support in the corporate law literature. ${ }^{23}$ The risk of misconduct is, so the argument goes, particularly acute at times of financial distress, where limited liability makes entrepreneurs feel that they have everything to gain, but nothing to lose, from gambling with creditors' money. Moreover, creditors' efforts to prevent such behaviour through contractual covenants and other devices are said to be hampered by information asymmetry and transaction cost problems. $^{24}$

However, whilst acceptance of this mantra is a key part of the case for creditor protection rules, ${ }^{25}$ there is in fact little hard evidence as to the true extent of the problem ${ }^{26}$ and the

Limited Liability in Corporation Law' (1980) 30 University of Toronto Law Journal 117; J Freedman, 'Limited Liability: Large Company Theory and Small Firms' (2000) 63 Modern Law Review 3.

${ }^{18}$ National Audit Office, Report by the Auditor and Comptroller General: Insolvency Service Executive Agency, Company Director Disqualification, (House of Commons Papers, Session 1992-1993, 907), (London, HMSO, 1993), para 1.4.

${ }^{19}$ CDDA, ss 7(1) \& 8(1).

${ }^{20}$ See eg Insolvency Act 1986 Sch B1 para 3(2) (duty of administrator to perform his or her functions in the interests of the creditors as a whole).

${ }^{21}$ See BIS, Small Business, Enterprise and Employment Bill: giving the Court and Secretary of State a Power to Make a Compensation Award against A Directors (BIS/14/932) 12, (available at: https://www.gov.uk/government/uploads/system/uploads/attachment_data/file/322856/bis_14_932_giv ing_the_court_and_SoS_a_power_to_make_a_compensatory_award_against_a_director.pdf).

22 ibid, 6 .

${ }^{23}$ Eg Landers, n 17; Freedman, n 17.

${ }^{24}$ Landers, Freedman, ibid.

25 See eg A Keay 'Wrongful Trading and the Liability of Company Directors: A Theoretical Perspective' [1996] Legal Studies 431, 434; P Davies \& S Worthington, Gower \& Davies: Principles of Modern Company Law (London: Sweet and Maxwell, $9^{\text {th }}$ ed, 2012) para. 9-6. 
relationship between limited liability and director misconduct is far from straightforward. A recent study by Gilje, ${ }^{27}$ for example, found no evidence of increased risk-taking by small US companies in the oil and gas industry in times of financial distress, reflecting the conclusions of an earlier study by Andrade and Kaplan ${ }^{28}$ Of course, this is not to say that increased, potentially undesirable, risk taking does not occur in any distressed firms. It may well do in certain cases. But whilst it is not hard to imagine that financial distress may tempt some corporate managers to misuse creditors' money, there are many reasons why this may not occur. Concern for reputation may be a powerful incentive for many entrepreneurs to avoid reckless or negligent trading, to say nothing of the fact that many directors, particularly director-shareholders of small companies, give personal guarantees for corporate debt and so give up much of their limited liability. ${ }^{29}$ Of course personal guarantees are most likely to be given to larger creditors, such as banks, ${ }^{30}$ and only compromise limited liability in respect of the creditors to whom the guarantees are given. But the fact that many entrepreneurs voluntarily give up their limited liability, even if only in respect of some creditors, should make us cautious in assuming too readily that the presence of limited liability necessarily creates increased risks of misconduct because of insulation from downside-risks.

The same is true when it comes to the apparent inability of creditors to develop sufficiently strong covenants to prevent abusive behaviour. To be sure, information asymmetries and transaction costs may prevent some creditors from effectively managing credit risks. But a wide variety of credit management tools are available, even to small businesses that may allow many others to effectively manage credit risks. Creditors who are not able to tailor their terms of credit to the individual circumstances of each debtors because of transactions costs or information asymmetries, for example, may nonetheless be able to adjust losses across groups of creditors by factoring expected levels of default into their pricing structures. ${ }^{31}$ Similarly, the availability of credit management tools such as debt factoring, where sums due on company invoices are sold to a third party (factor) as a discount, ${ }^{32}$ or purchasing trade credit insurance, ${ }^{33}$ where the creditor purchases insurance against the risk of default by the debtor, provide potentially effective means to manage credit risks, even for small firms. Trade credit insurance in particular provides a mechanism for individual debtors to overcome information asymmetry and transaction cost problems by pooling resources with other creditors in the insurer, who undertakes credit checks on corporate debtors in setting the terms of insurance cover.

For its part the Department for Business acknowledged doubt as to the extent of the 'market failure' problem in its impact assessment of the new powers, but commented that whilst this

\footnotetext{
${ }^{26}$ See Halpern, et al, n 17, who come to 'empirical intuition' that these costs of limited liability are likely to outweigh their benefits in small firms.

${ }^{27}$ E Gilje, 'Do Firms Engage in Risk Shifting? Empirical Evidence', presented at Oxford-LSE Law and Finance Conference, 23 May 2014 (available at https://testintranet.law.ox.ac.uk/ckfinder/userfiles/files/Erik\%20Gilje\%20paper.pdf).

${ }^{28}$ G Andrade \& S N Kaplan, 'How costly is Financial (not Economic) Distress? Evidence from Highly Leveraged Transactions that became Distressed' (1998) 53 Journal of Finance, $1443,1471$.

${ }^{29}$ See eg J Freedman and M Godwin, 'Incorporating the Micro business: Perceptions and misperceptions' in A Hughes and D Story (eds), Finance and the Small Firm (London: Routledge, 1994). 
might be relevant to the use of the new powers it did not alter the need for them. ${ }^{34}$ Now it is certainly not the argument of this paper that the 'market failure' case for public regulation to protect creditors is without any foundation. But uncertainty about the extent of the problem is relevant to the need for the new powers. And this is particularly true in the context of the sort of cost-benefit analysis that the UK Government itself put forward in making the case for the new civil recovery powers.

\section{Cost-Benefit Analysis}

The Department for Business' Impact Assessment ${ }^{35}$ of the new powers sets out in some detail their expected 'monetised' costs against their potential 'monetised' benefits to creditors. In such an analysis doubt as to the potential gains of the new rule is obviously relevant to the question of whether the rule is needed at all and not simply to the extent of its use; the fact that a market failure may occur is only the starting point for analysing whether remedial regulation is justified in cost-benefit terms, it is not the final word. Rather, regulation will only be justified on such a basis if it is likely to improve on market outcomes, in the sense of bringing about a net increase in wealth, once the full costs and benefits of regulation are taken into account. ${ }^{36}$ Thus, the smaller the scale of the problem that regulation is intended to resolve then the lower the potential gains from the regulation will be and, correspondingly, greater is the chance that the costs of regulation may outweigh its benefits.

Of course, the desirability of using cost-benefit or wealth maximisation analysis to determine whether a particular form of regulation is 'good' regulation is disputed. ${ }^{37}$ Cost-benefit analysis may legitimate the imposition of costs on individuals groups against their will, and tends to assume that units of currency have equal value for all groups in society ${ }^{38}$. Further, analysis of monetised costs and benefits ignores questions of justice and fairness ${ }^{39}$ and may fail to capture the true impact of the rule in simply setting one pound, euro or dollar of 'benefit' against another pound, euro or dollar of 'cost'. However, accepting the potential limitations of cost-benefit analysis, it is clear that the primary goal of the new powers is financial, and narrowly so - to increase the flow of financial compensation to creditors of insolvent companies. ${ }^{40}$ As such some form of cost-benefit testing is an essential and inevitable part of analysis of the rule. ${ }^{41}$

Exact ex ante quantification of the costs and benefits of the new powers is, of course, impossible and it will certainly not be claimed in this paper that the new powers are not justified because the costs of the new rules outweigh, or equal, their benefits. But accepting the validity of cost-benefit testing it is submitted here that the new powers should at least offer the prospect of a significant net recovery for creditors to be a worthwhile reform. If the rule is not likely to offer such a surplus, then it cannot, on the Government's own measure, be justified simply because some scope for some regulation may exist. Other forms of regulation, or no regulation at all, may be a better choice.

\section{Are Existing Civil Recovery Powers Insufficient?}

\footnotetext{
${ }^{34}$ Small Business, Enterprise and Employment Bill: giving the Court and Secretary of State a Power to Make a Compensation Award against A Directors (BIS/14/932), n 21.

35 ibid.

${ }^{36}$ See generally, Ogus, Regulation: Legal Form and Economic Theory, n 16, ch 8

${ }^{37}$ See, for example, R Dworkin, 'Is Wealth Value?' (1980) 9 Journal of Legal Studies 191; A

Kronman, 'Wealth Maximisation as a Normative Principle' (1980) 9 Journal of Legal Studies 227; R Baldwin, Rules and Government, (Oxford: OUP, 1995). See also Ogus, ibid, ch 8.

${ }^{38}$ Ogus, ibid, 25.

${ }^{39}$ See, eg Baldwin, n 37, 25-26.

${ }^{40}$ Department for Business, Innovation and Skills, Transparency and Trust: Enhancing the

Transparency of UK Company Ownership and Increasing Trust in UK Businesses, n 6.

${ }^{41}$ Ogus, n 36, 153.
} 
So what then of existing civil recovery powers? Can we be sure, as is implicit in the claim that the new powers are needed to improve financial redress for creditors, that existing rules leave significant untapped wells of civil recovery for creditors of failed companies? Well, the available evidence does not suggest that this is the case. Rather it tends to support the contention that the scope for civil recovery against errant directors is limited.

To be sure, the effectiveness of existing personal liability rules against errant directors, notably the wrongful trading remedy, have been questioned. Low numbers of reported cases under that remedy in particular have sustained claims that the rule fails to effectively protect creditors and so, by implication, fails to secure civil compensation in cases where it could be available. Much of this criticism the wrongful trading rule concerns an apparent ability of insolvency practitioners (ie liquidators and administrators) to utilise their statutory recovery powers because of costs issues. In general terms, the costs of litigation for civil recovery actions under the IA 1986 are recoverable from an insolvent company's estate as part of the expenses that an office holder incurs in the proper execution of their duties. ${ }^{42}$ However, where the costs of recovery litigation are likely to be high and so where the assets of the company are limited, insolvency practitioners may simply feel unable to pursue civil recovery proceedings. ${ }^{43}$ The conclusion that cost issues place significant constraints on existing remedies has, of course, been accepted by the UK Government. Proposals elsewhere in the SBEE seek to unlock such funding constraints by permitting creditor funding of civil recovery actions under sections 214, 213, 238 and 239 IA 1986 by granting liquidators (and administrators) a new power to assign statutory claims to third parties. ${ }^{44}$

So, to the extent that existing powers of civil recovery are held back by costs constraints, then it might be expected that civil recovery in disqualification would yield greater returns for creditors than have been secured from existing powers. Compensation cases under the new rules will be brought by the state and so be unaffected by the cost issues affecting recovery by insolvency practitioners.

However, the difficulty with this argument is that there is scant evidence that cost constraints have significantly held back existing remedies. Conditional fee arrangements (CFAs) including so called "uplift fees ${ }^{45}$ (allowing the successful litigants legal fees to be recovered from the losing party) have, for example, been widely used ${ }^{46}$ by insolvency practitioners to

\footnotetext{
${ }^{42}$ Insolvency Rules 1986 (SI 1986/1925), r 4.218(1) (as amended by Insolvency (Amendment) Rules 2008 (SI 2008/737)). See further Finch, Corporate Insolvency Law, n 32, 555.

${ }^{43}$ See further A Keay, 'Company Directors Responsibility to Creditors (London: RoutledgeCavendish, 1997), 131-136; D Prentice, 'Corporate Personality, Limited Liability and the Protection of Creditors' in R Grantham and C Rickett (eds) Corporate Personality in the $20^{\text {th }}$ Century (Oxford: Hart, 1998)123- 125; R J Mokal, Corporate Insolvency Law (Oxford: OUP, 2005) 281-282. Cf R Williams, 'What Can we Expect to Gain from Reforming the Insolvent Trading Remedy?' n 4.

${ }^{44}$ Small Business, Enterprise and Employment Act 2015, ss 117 -119. See also, Department for Business, Innovation and Skills, Transparency and Trust: Enhancing the Transparency of UK Company Ownership and Increasing Trust in UK Businesses, n 3, 11.1-11.12.

${ }^{45}$ Uplift Fees are, however, to be phased out of insolvency litigation from April 2015 as a result of the provisions of Legal Aid, Sentencing and Punishment of Offenders Act 2012.

${ }^{46}$ It has been suggested that up to $90 \%$ of wrongful trading actions were brought on the basis of a conditional fee arrangement, for example (Small Business, Enterprise and Employment Bill: Enabling Liquidators Impact Assessment (BIS 14/931) 8, (available at https://www.gov.uk/government/uploads/system/uploads/attachment_data/file/322337/Enabling_Liqui dators_and_Administrators_to_assign_to_third_parties_certain_rights_of_action_that_only_they_can_ bring_under_the_Insolvency_Act_1986.pdf). See also P Walton, The Likely Effect of the Jackson Reforms on Insolvency Litigation: An empirical Investigation (Association of Business Rescue Recovery Professionals, 2014), available at https://www.r3.org.uk/media/documents/policy/Jackson_Campaign/Jackson_Reforms_Insolvency_Liti gation_April_2014.pdf (last accessed 6 November 2014)
} 
alleviate cost concerns in insolvency litigation, so it is far from certain that costs issues have had such dramatic impact that we can be sure than an as yet untapped reservoir of potential civil compensation exists, at least since CFAs came widely into use.

Analysis of reported cases, of course, does suggest that levels of litigation under some key civil recovery powers, such as the wrongful trading rule in section 214 IA 1986, have been low. A recent study suggests, for example, that just 16 cases dealing with a substantive claim have been reported under section 214 between 1986 and 2013, ${ }^{47}$ though the incidence of reported cases under other provisions is somewhat higher, with over 60 misfeasance claims against directors reported under section 212 IA 1986 and higher numbers of cases reported under sections 238 and 239 (though these remedies do not exclusively concern civil liability actions against wrongdoing directors). ${ }^{48}$ However, there is no convincing evidence to suggest that this level of reported cases is dramatically out of line with opportunities for civil recovery against wrongdoing directors, given that reported cases represent only a part of civil recovery actions. In the specific case of the section 214 rule, it has been shown, for example, that levels of reported litigation are not dramatically out of line with instances of insolvent trading recorded in disqualification cases, despite a lower standard for culpability being applied than is the case under section 214 and the cost of disqualification proceedings falling on the State. ${ }^{49}$

In so much as it is therefore unclear that existing powers underperform relative to available opportunities for civil recovery then prospects for a significant upswing in civil recovery as a result of the new powers are uncertain. Indeed, the lack of any clear evidence that existing remedies leave significant amounts of potential recovery untapped lends support to doubts as to as to the frequency of the 'market failure' problem to which both the old and new rules respond. In short, there may be few civil recovery cases under existing rules because the need for recovery is limited and not because existing remedies are especially ineffective.

\section{Civil Recovery in Disqualification: Insolvency Practitioner Incentives}

That said, of course, the new civil recovery powers do directly address a long-standing criticism of the disqualification rules, namely that they offer no direct benefit to the victims of unfit conduct. ${ }^{50}$ Instead the core disqualification rules seek to protect creditors by taking unfit directors 'off the road' for a period of time and by the deterrence of misconduct ${ }^{51}$. In both respects the effectiveness of disqualification has been questioned. ${ }^{52}$

Civil recovery powers certainly offer the prospect that creditors may, at least in some cases, benefit more directly from disqualification. However, whether this will result in a net increase in recovery for creditors is unclear and the sections below in this paper argue that any increase is unlikely to be large. However, whatever its impact on overall levels of recovery, the new rules seem much more likely to have an important impact on patterns of recovery.

\footnotetext{
${ }^{47}$ Williams, n 4, 60.

${ }^{48}$ Williams, ibid, 61.

${ }^{49}$ Williams, ibid, 72.

${ }^{50}$ See eg A Hicks, Disqualification of Directors: No Hiding Place for the Unit? (London: Certified Accountants Educational Trust, 1998).

${ }^{51}$ See eg Re Blacksupr Group plc [1998] 1 WLR 422, 426 (per Lord Woolfe MR); National Audit

Office, Report by the Comptroller and Auditor General, Insolvency Service Executive Agency, Company Director Disqualification - A Follow-Up Report, (House of Commons Papers, Session 1998-1999, 424), para 1.5.

${ }^{52}$ See eg R Williams, 'Disqualifying Directors: A Remedy Worse than the Disease?' (2007) 7 JCLS 253.
} 
Granting the State civil recovery powers has obvious potential to reduce the incentive for insolvency practitioners to use existing powers of recovery against directors. Under the new arrangements the financial risk of launching recovery proceedings will fall on the state and they seem likely to have the effect of encouraging insolvency practitioners to shift the financial burden of civil recovery powers from the estate of insolvent corporations to the state, by using the statutory reporting machinery ${ }^{53}$ of the disqualification regime to emphasise opportunities for civil recovery in disqualification. As such, any 'increases' in civil recovery under the new powers could be offset by decreases in recovery under the old powers.

For its part the Insolvency Service argues that the risk that the new powers will act as a disincentive to recovery by insolvency practitioners is low because sums recovered from wrongdoing directors will, in the main, go straight to creditors and will not be available to insolvency practitioners to pay their fees as a contribution to the general assets of the company. ${ }^{54}$ That argument, though, takes a rather cynical view of the motivations of insolvency practitioners in launching civil recovery proceedings under existing powers. It seems altogether strange that any insolvency practitioner would launch civil recovery proceedings simply with the aim of securing payment of his or her fees, given the inherent risks and uncertainties of litigation. Much more likely, surely, is that those risks would tempt many insolvency practitioners to pass issues of civil recovery to the Secretary of State, which after all, could well be the lowest risk way of securing the highest compensation for creditors. Passing the costs of recovery to the State lowers the expenses of the liquidation through lower insolvency practitioner fees and creates no risk of litigation costs falling on creditors, enabling the office holder to achieve a better return for creditors in a shorter time scale.

\section{PERSONAL INSOLVENCY AND WRONGDOING DIRECTORS: A STUDY}

\section{Corporate Failure and Director Insolvency}

Uncertainty as to the need for the new civil recovery powers makes it crucial that the new powers offer the prospect of bringing about significant recovery from wrongdoing directors if, on balance, they are to meet the goal of enhancing overall recovery for creditors. A crucial determinant of the success of the new powers in this respect will be the ability of directors to pay compensation to creditors. Corporate failure may, however, have a significant negative impact on the personal finances of directors and so limit the practical benefit of civil recovery rules.

The exposure of many directors and managers to financial harm in the event of corporate insolvency is well documented. A 1994 study of small businesses by Freedman and Godwin, for example, found that owners or managers of over half of the companies surveyed had given a personal guarantee to secure corporate debt. ${ }^{55}$ As one would expect, the survey, in common with others, showed that the majority of guarantees had been given to large and well resources creditors, such as banks ${ }^{56}$ rather than to smaller scale creditors. Bank finance to small companies will typically be provided in the form of loans or agreed bank overdraft

\footnotetext{
${ }^{53}$ Company Directors Disqualification Act 1986, s 7.

${ }^{54}$ Department for Business, Innovation and Skills, Small Business, Enterprise and Employment Bill: giving the Court and Secretary of State a Power to Make a Compensation Award against A Directors, n19, 16.

${ }^{55}$ Freedman and Godwin, n 29. See also A Hicks, R Drury and J Smallcombe, Alternative Business Structures for Small Businesses: ACCA Research Report (London: Certified Accountants Educational Trust, 1995); J Franks and O Sussman, 'Financial Distress and Bank Restructuring of Small to Medium Size UK Companies' (2005) 9 Review of Finance 65, 80.

${ }^{56}$ Freedman and Godwin, ibid; Hicks, Drury and Smallcombe, ibid; and Franks and Sussman, ibid. See also R Avery, R Bostic \& K Samolyuk, 'The Role of Personal Wealth in Small Business Finance' (1998) 22 Journal of Banking and Finance 1019.
} 
facilities,${ }^{57}$ and so personal guarantees likely consist of fixed calls on director's personal wealth, at least up to the limit of an overdraft facility or loan. As well personal guarantees, many owner-managers provide significant financial support to their companies in the form of direct loans to the business. A study by Hughes suggests that around 20 per cent of SMEs relied on director/manager loans for a significant part of their finance. ${ }^{58}$ This pattern of 'selffinancing' of business tends to change markedly over the lifetime of a company, being much more important in the early years of trading than when the business has become established ${ }^{59}$. Self-financing is, however, likely to be an important source of support for distressed ownermanaged business as other avenues of credit close.

The exposure of many entrepreneurs to downside financial risks from their business creates an obvious likelihood that corporate insolvency will bring personal financial distress, and this may limit the usefulness of civil liability rules. ${ }^{60}$ This is all the more so as it is likely to negatively impact on the 'credit' side of a director's personal balance sheet, as well as the 'debt side' that is, it is likely to extinguish or significantly reduce their income as well as bring liability for (at least part) of corporate debts. So it is to be expected that the incidence of personal financial distress will be higher amongst directors of failed companies than the population at large. This will inevitably place some limits on the reach of civil recovery provisions, whether old or new, but understanding how much of a limit is crucial to assessing the likely impact of the new powers as well as gaining a better understanding of the context in which the existing rules operate. The Department of Business cited no specific analysis of this question in the detailed case made for the rules, though its analysis did include a discount of 10 per cent on potential proceeds of recovery to account for cases where recovery failed because directors were unable to pay. ${ }^{61}$ This figure, though, appears based on analysis of an unspecified sample of disqualification cases where the Insolvency Service had been unable to recover costs from disqualified directors drawn from a separate policy document (no basis for the discount is cited in the Impact Assessment of the disqualification reforms ${ }^{62}$ ), rather than on a specific analysis of bankruptcy rates amongst the target group of directors.

\section{Directors' Ability to Pay Compensation: Empirical Analysis of Bankruptcy Amongst} Disqualified Directors.

In order to enable a full assessment of the potential of the new powers to bring about significant levels of new civil recovery, a study of the incidence of personal bankruptcy amongst wrongdoing directors was carried out by comparing records of 456 individuals disqualified for unfit conduct under sections 6 or 8 of the CDDA between January and July 2008 against records of bankruptcy notices published the London Gazette, using the Gazette's

\footnotetext{
57 ibid.

${ }^{58}$ The figure among 'micro' business (those employing less than 10 people) was $24.6 \%$, see A Hughes, 'Finance for SME's: A UK perspective' (1997) 9 Small Business Economics 151,table II .

${ }^{59}$ Freedman and Godwin, n 29. See also A Cosh \& D Hughes, British Enterprise in Transition (2000) Centre for Business Research, University of Cambridge, Chapter 5.

${ }^{60}$ See eg Cheffins, n 31, 81-82.

${ }^{61}$ Department for Business, Innovation and Skills, Small Business, Enterprise and Employment Bill: giving the Court and Secretary of State a Power to Make a Compensation Award against A Directors, n19, 15.

${ }^{62}$ Department for Business, Innovation and Skill, Enabling Liquidators and Administrators to assign to third parties certain rights of action that only they can bring under the Insolvency Act 1986 and to extend the right to bring fraudulent and wrongful trading actions to an administrator (BIS 14/931), 11, available at https://www.gov.uk/government/uploads/system/uploads/attachment_data/file/322337/Enabling_Liqui dators and Administrators to assign to third parties certain rights of action that only they can bring under the Insolvency Act 1986.pdf (last accessed 15th November 2014).
} 
online search facility. ${ }^{63}$ The 2008 disqualification records were collected for an earlier study of disqualification undertakings ${ }^{64}$ and were used as the basis for this study as they allowed for analysis of personal bankruptcy of disqualified directors in the period after disqualification when applications for civil recovery may be made, and in the period leading up to disqualification. A study of contemporary disqualifications would only allow analysis of bankruptcy in the period before disqualification and so be less useful in assessing the likelihood of disqualified directors being able to satisfy a civil recovery order in the period after disqualification occurred (ie the period when they would become liable to pay compensation awards).

The study was carried out by entering the names of disqualified individuals into the Gazette's on-line search facility (restricting the search to 'bankruptcy orders' in the personal insolvency filter), and checking the details of the returned 'hits' against details of the directors contained in disqualification notices. All confirmed bankruptcies of disqualified individuals that occurred on or after the date of the insolvency of the company of which the disqualified individual acted as a director (with a grace period of 4 weeks) were recorded in the survey. For the purpose of this analysis the date of corporate insolvency was defined as, in voluntary proceedings, the date at which the company entered formal insolvency proceedings (liquidation, administration etc) as recorded on Companies House records, ${ }^{65}$ or, in the case of compulsory winding up proceedings, the date upon which a petition for winding up was presented to the court, again as recorded in Companies House records. The majority of corporate insolvencies to which the disqualification cases in the survey were related took place in 2006, as would be expected given the typical two year interval between corporate insolvency and disqualification, with smaller numbers in 2005 and 2007.

The disqualification records used as the basis of the survey contained a statement of the directors' full name, date of birth, details of their home address as well as the name of the companies of which there were lately a director. Bankruptcy notices were more varied in the information they contained. All stated the name of the bankrupt, with most stating the bankrupt's home address and occupation. Some records stated the date of birth of the bankrupt and, if he or she were a director, the name of their company. ${ }^{66}$

A disqualified individual was identified as a bankrupt for the survey where their name, plus at least one piece of data in the bankruptcy record (ie date of birth, address or occupation) exactly matched that in the disqualification record. In the vast majority of positive results the matching data were full name plus address, sometimes with other data matching alongside (eg date of birth or occupation listed as 'director'). In a small number of cases address details in the bankruptcy record did not match those in the disqualification record, but name and date of birth details were sufficient to establish the bankruptcy of the disqualified individual. In another small number of cases a name match was not accompanied by other matching data, but it nonetheless seemed likely that the bankruptcy record did relate to a disqualified individual. These records, of which there were three, are not included in the data set presented below. Each of these cases was regarded as a likely match on the basis that whilst the addressees in the two records did not match, both listed an address in the same postal town and the date of bankruptcy corresponded to the date the individual was disqualified or the

\footnotetext{
${ }^{63}$ Available at: https://www.thegazette.co.uk/insolvency. Note of bankruptcy orders made by the court are required to be 'Gazzetted' by the official receiver (see Insolvency Rules 1986, r 6.46(2)(a)(ii)) (orders following a debtor's petition); r 6.34(2)(a)(ii) (creditor's petition)).

${ }^{64}$ See R Williams, Disqualification Undertakings: Law, Policy and Practice n 14, Ch 5.

${ }^{65}$ Records of corporate insolvency were checked using the Companies House 'WebCheck' service, available at: http://wck2.companieshouse.gov.uk//wcframe?name=accessCompanyInfo.

${ }^{66}$ The required contents of Gazette notices relating to bankrupts are set out in the Insolvency Rules 1986 (SI 1986/1925), r 12A.35.
} 
date of the corporate insolvency in which they were involved. Nonetheless, the cases were excluded from the data set because of the absence of a second piece of matching data.

\section{Bankruptcy Amongst Disqualified Directors.}

Analysis of the study group of 456 disqualified directors showed that 102 of those directors were declared bankrupt between the date of the insolvency of their company and the cut-off date for the survey, which was 1 December 2013. This equates to a bankruptcy rate of just over 22 per cent amongst the all of the wrongdoing directors in the sample.

Of the 102 bankrupts in the study, the majority (54) were declared bankrupt either before or at the same as they were disqualified. The remainder of the disqualified bankrupts (48) were declared bankrupt after their disqualification under the CDDA. In respect of the latter group, individuals were most likely to be declared bankrupt in the immediate aftermath of disqualification. As set out in Table 1 below, 32 of the 48 individuals were declared bankrupt within two years of disqualification, with most of those bankruptcies occurring within 18 months of disqualification. A further four individuals were declared bankrupt between 2-3 years after disqualification, and 12 directors were declared bankrupt more than 4 years after disqualification. In nine of those 12 cases, disqualified individuals were declared bankrupt between 4-5 years after disqualification, ${ }^{67}$ with bankruptcy in the three remaining cases occurring more than 5 years after disqualification.

Table 1. Individuals Declared Bankrupt after Disqualification: Period between Disqualification and Bankruptcy

\begin{tabular}{|l|l|}
\hline $\begin{array}{l}\text { Period after } \\
\text { Disqualification } \\
\text { (months) }\end{array}$ & $\begin{array}{l}\text { Number of Individuals } \\
\text { Declared Bankrupt. }\end{array}$ \\
\hline $0-6$ & 18 \\
\hline $7-12$ & 4 \\
\hline $13-18$ & 7 \\
\hline $19-24$ & 3 \\
\hline $25-30$ & 1 \\
\hline $31-36$ & 3 \\
\hline $37-48$ & 0 \\
\hline $49-54$ & 7 \\
\hline $54-60$ & 2 \\
\hline $60+$ & 3 \\
\hline
\end{tabular}

Under the current legislative proposals the Secretary of State will be permitted to apply for a compensation order against a disqualified individual for up to two years from the date of their disqualification. ${ }^{68}$ As such, civil recovery is unlikely to be effective against directors who are declared bankrupt within that two-year period. Of course, some period of time is likely to be given to directors to pay a compensation order, so the period during which director solvency is likely to affect their ability to pay compensation will in reality stretch beyond the two-year limit, which is simply a limit on the Secretary of State's ability to apply for an order. Furthermore, the imposition of a compensation order may well hasten the insolvency of

\footnotetext{
${ }^{67}$ In both cases the individuals were declared bankrupt in July 2013, having been disqualified in April and May 2008 respectively.

${ }^{68}$ Small Business, Enterprise and Employment Act 2015, s 110 (inserting new s 15A of the Company

Directors Disqualification Act 1986).
} 
individuals who otherwise would not become insolvent until a later time (assuming, of course, that bankruptcy is the end point of a significant period of financial strain). On this basis it seems reasonable that the effectiveness (from the creditors' perspective) of civil recovery would be in significant doubt in cases where an individual is declared bankrupt, either before disqualification, or within 3.5 years after disqualification. Of course, that is not to say that bankruptcy after the 3.5 year period may not also prevent compensation from being obtained. Bankruptcy four years after disqualification, for example, may well have been preceded by a long period of financial distress and the imposition of a significant civil penalty may simply hasten the date of bankruptcy. But equally it could be the case that bankruptcy after this period may well not impact on a directors' ability to fulfil a compensation order, at least if it is obtained shortly after disqualification. On the assumption therefore that the effectiveness of civil recovery is likely to be in significant doubt against directors declared bankrupt between corporate insolvency and 3.5 years after disqualification, the study suggests that civil recovery is unlikely to be effective in respect of $\mathbf{2 0}$ per cent $(90 / 456)$ of disqualified directors.

This overall figure, however, conceals significant variations in the likelihood of bankruptcy according to the period of time for which an individual was disqualified. So, as is shown in Table 2, by breaking down the restricted sample of 90 disqualified bankrupts ${ }^{69}$ according to the Sevenoaks ${ }^{70}$ bracket periods of disqualification (indicating seriousness of misconduct), the rate of bankruptcy in 'less serious' cases (2-5 years disqualification) was just over 13 per cent. In the middle bracket of cases of 6-10 years, indicating more serious misconduct, though not "cases not involving conduct meriting the highest period of disqualification", ${ }^{71}$ the incidence of bankruptcy was double that in the lowest bracket, at just over 26 per cent. In the highest bracket of 11-15 years disqualification (for "particularly serious" ${ }^{172}$ cases of misconduct), the incidence of bankruptcy was a little over 30 per cent. The combined bankruptcy rate for the two higher brackets of cases was $\mathbf{2 7 . 2 7}$ per cent. This higher rate of bankruptcy amongst directors disqualified for longer periods is particularly significant because the Department for Business has made clear that the new powers will be used to target directors responsible for the most serious misconduct, that is those disqualified for 6 or more years. ${ }^{73}$

\footnotetext{
${ }^{69}$ That is, excluding directors declared bankrupt more than four years after disqualification.

${ }^{70}$ Re Sevenoaks Stationers (Retail) Ltd [1991] Ch 164.

71 ibid, 174.

72 ibid.

${ }^{73}$ Department for Business, Innovation and Skills, Small Business, Enterprise and Employment Bill: giving the Court and Secretary of State a Power to Make a Compensation Award against A Directors, n 21, 11 .
} 
Table 2. Incidence of Bankruptcy According to Period of Disqualification (individuals declared bankrupt up to 3.5 years after disqualification).

\begin{tabular}{|l|l|l|l|}
\hline $\begin{array}{l}\text { Period of } \\
\text { Disqualification }\end{array}$ & $\begin{array}{l}\text { Number of } \\
\text { Individuals } \\
\text { Declared } \\
\text { Bankrupt }\end{array}$ & $\begin{array}{l}\text { Number of } \\
\text { Individuals in } \\
\text { sample }\end{array}$ & $\begin{array}{l}\text { Incidence of } \\
\text { Bankruptcy (\%) }\end{array}$ \\
\hline 2-5 years & 33 & 247 & 13.36 \\
\hline 6-10 years & 40 & 153 & 26.14 \\
\hline 11-15 years & 17 & 56 & 30.36 \\
\hline $\begin{array}{l}\text { 6-15 years } \\
\text { (combined totals) }\end{array}$ & $\mathbf{5 7}$ & $\mathbf{2 0 6}$ & $\mathbf{2 7 . 2 7}$ \\
\hline
\end{tabular}

It hardly need be stated that the results of the survey show that the incidence of bankruptcy amongst wrongdoing directors is markedly higher than it is amongst the population as a whole. Insolvency Service statistics for the period of 2006-2011 show that the average incidence of bankruptcy amongst the adult population of England and Wales was 14.26 cases per 10,000 individuals across the period. ${ }^{74}$ In percentage terms, this equates to an incidence of bankruptcy of just $\mathbf{0 . 0 0 1 4 2 6}$ per cent. The annual figures published by the Insolvency Service were highest in 2009 at 17.9 cases of bankruptcy per 10,000, but had declined to 9.3 cases per 10,000 by 2011 . The figures for 2006- 8 were $14.9,15.1$ and 15.7 respectively with the figure for 2010 being $13.4 .^{75}$

According to the survey, disqualified individuals are therefore more likely to be declared bankrupt than the population as whole by a factor of some 13,800. In the case of directors disqualified for more than 6 years, the figure is even higher, with the incidence of bankruptcy (at 27.27 per cent) being 19,000 times greater than that for the population at large. It is clear therefore that disqualified directors are, to put it mildly, significantly more likely to suffer bankruptcy than the population as a whole.

\section{Wrongdoing Directors and Other Forms of Personal Insolvency.}

Aside from formal bankruptcy, of course, many other wrongdoing, disqualified, directors are likely to suffer personal financial distress that reduces or extinguishes their ability to pay compensation to creditors. Insolvency Service statistics show, for example, bankruptcies accounted for only half (52.36 per cent) of all officially recorded personal insolvencies between 2006-2011 period, with Individual Voluntary Agreements (IVAs) accounting for 38.5 per cent of insolvencies and the remainder Debt Relief Orders (DROs). ${ }^{76}$

IVAs were first introduced in the UK following the recommendation of the Cork Report that an alterative to bankruptcy proceedings for financially distressed individuals should be introduced to facilitate voluntary settlements with creditors. ${ }^{77}$ The essence of the IVA is, as its name suggests, an uncontested settlement between the debtor and his or her creditors to manage financial difficulties whereby creditors typically agree to write off a certain portion of the debtor's liability in return for a structured repayment schedule of part of the debts

\footnotetext{
${ }^{74}$ Insolvency Service, Individual Insolvencies by region and local authority (published 10 July 2014, available at https://www.gov.uk/government/statistics/insolvency-statistics-individual-insolvencies-byregion-2013 (last accessed 6 November 2014).

75 ibid.

76 ibid.

${ }^{77}$ Cork Report, n 10, Ch 7.
} 
alongside certain other guarantees. ${ }^{78}$ Debt relief orders are a more recent innovation that provide a mechanism for resolving small debts (up to a maximum of £20,000) in cases where the debtor has no assets or assets valued at no more than $£ 1000 .{ }^{79}$

Unlike bankruptcy cases, there is no requirement for notice of an IVA or DRO to be made in a place of permanent record, such as the Gazette. The names of individuals subject to these proceedings are entered on to the Insolvency Service register of personal insolvencies ${ }^{80}$, but these details are deleted from the register no later than three months after the cessation of an $\mathrm{IVA}^{81}$ or upon receiving notice of the end of a DRO ${ }^{82}$ There is, as such, no available public record that allows identification of the number of disqualified individuals in the sample group who entered into an IVA, or a DRO during the relevant period for civil recovery. Nonetheless, it seems reasonable to suppose that a number of disqualified individuals who do not enter formal bankruptcy proceedings would have entered one or other of these proceedings.

Insolvency Service figures, again for the adult population of England and Wales, show that the rate of IVAs per 10,000 of population averaged at 10.5 over the $2006-2011$ period. ${ }^{83}$ In respect of DROs the rates for the first three years of operation of the orders were 5.7 per 10,000 in 2010, 6.6 in 2011 and 7 in 2012. ${ }^{84}$ The introduction of DROs in 2009 seems not to have had an impact on the number of IVAs or bankruptcies registered with the Insolvency Service ${ }^{85}$ The average rate of individual insolvencies across the 2006-2011 period per 10,000 of population was therefore $25.71,{ }^{86}$ of which, as we have seen, bankruptcies accounted for 14.26 insolvencies per 10,000 adults.

Of course, it should be stressed the IVA, and to a lesser extent the DRO, does not release the debtor entirely of an obligation to repay. Both take the form of structured settlement procedures. Nonetheless, it seems unlikely that civil recovery would be effective against disqualified individuals subject to IVAs or DROs. In the case of an IVA, at the very least it would be unlikely that the individual would be able to pay the full amount of compensation ordered, but more likely the extra liability may simply tip them into formal bankruptcy. Recovery proceedings against an individual subject to a DRO would, by definition be hopeless, given that they apply only persons with assets of less than $£ 1000$.

On the assumption therefore, that incidence of IVAs and DROs amongst wrongdoing directors was equivalent to the incidence of bankruptcy (that is that disqualified individuals are more likely to be subject to an IVA or DRO than the population as a whole at the same rate as they are more likely to be declared bankrupt), then it could be the case that up to 40

\footnotetext{
${ }^{78}$ See generally S Morgan, N Smyth \& J Tribe, Personal Insolvency Law in Practice, (Bristol: Jordan Publishing, 2013) ch 9.

${ }^{79}$ Insolvency Proceedings (Monetary Limits) Order 1986 (SI 1986/1996), sch 1, part II, para 1 and Insolvency Act 1986, sch 4ZA, paras 6(1), 7(1) \& 8(1) (as amended by Insolvency Proceedings (Monetary Limits) (Amendment) Order 2015 (SI 2015/26)).

${ }^{80}$ The register is available at: https://www.insolvencydirect.bis.gov.uk/eiir/.

${ }^{81}$ Insolvency Rules 1986 (SI 1986/1925) r 6A.3.

${ }^{82}$ Insolvency Rules 1986 (SI 1986/1925) r 6A.7B.

${ }^{83}$ Annual numbers are: 11.1 (2011); 11.5 (2010); 11 (2009); 9.1 (2008); 9.9 (2007); 10.5 (2006). See Insolvency Service Statistical Release, Individual Voluntary Agreements by Area, available at http://www.insolvencydirect.bis.gov.uk/otherinformation/statistics/regionalstatisticsmenu.htm. ${ }^{84}$ Insolvency Service statistical release, Debt Relief Orders (DROs) by area, available at http://www.insolvencydirect.bis.gov.uk/otherinformation/statistics/regionalstatisticsmenu.htm. ${ }^{85}$ See nn 14 and 19.

${ }^{86}$ Figures for individual years were 25.4 (2006); 25.1 (2007); 24.8 (2008); 30.9 (2009); 30.7 (2010); 26.9 (2011). See Insolvency Service statistical release, Total Individual Insolvencies by Area, available at http://www.insolvencydirect.bis.gov.uk/otherinformation/statistics/regionalstatisticsmenu.htm.
} 
per cent of disqualified directors in the sample could have been involved in a formal personal insolvency procedure, on the basis that bankruptcies accounted for roughly half of all personal insolvencies across the 2006-2011 period. In the case of directors disqualified for more than six years, the incidence of personal insolvency proceedings could, on this measure, be over 50 per cent (ie a little under double the 27.27 per cent that were declared bankrupt). Of course, if disqualified individuals are more likely to enter bankruptcy than an IVA or DRO, perhaps because corporate insolvency causes particularly acute personal financial loss to many directors (eg as a the result of personal guarantees give to corporate creditors, total loss of income etc.) then the figures may be somewhat lower. Without access to a complete historic record of IVAs (and DROs) it is not possible to predict the incidence of IVAs amongst the sample group of disqualified directors more accurately. But the higher incidence of bankruptcy amongst disqualified individuals does make it likely that incidences of IVAs and DROs are also significantly higher amongst the group. But at the very least it is clear that the incidence of formal personal insolvency amongst disqualified directors is higher than the incidence of bankruptcy alone. And this, of course, is to say nothing of those individuals who suffer financial distress but avoid formal insolvency proceedings. For this group a civil liability penalty on top of disqualification may simply have the effect of pushing them into formal proceedings, in which cases creditors could expect to gain little from recovery proceedings.

Nonetheless, a high incidence of personal insolvency amongst disqualified directors is likely to place real limits on the benefits of the new civil recovery powers. This is all the more so given that insolvency rates are highest amongst directors disqualified for more serious misconduct, which is the group against which the Impact Assessment states the powers will be targeted. Indeed, this fits with the results of an admittedly small study of directors made liable for wrongful trading under section 214 IA 1986 between 1986-2013, which found evidence that seven of 12 traceable directors made so liable declared bankruptcy shortly after liability was imposed on them. ${ }^{87}$

\section{E. FINANCIAL HARM AND UNFIT CONDUCT CASES}

In addition to director solvency, a particular determinant of the impact of the new powers is the identification of financial loss from unfit conduct. As such, the nature of the conduct for which a person is disqualified has a crucial bearing on the amount, if any, of compensation that a person may be required to pay. This is significant because many disqualifications concern conduct by directors that is difficult to relate to specific losses by creditors, or at least, creditors who are not the Crown.

Most disqualified directors are found unfit to be concerned in the management of companies either because they have, in the words of disqualification, 'discriminated against the Crown', in failing to pay debts owed to Crown agencies whilst satisfying the claims of a least some other creditors, ${ }^{88}$ or because they have failed to 'maintain, preserve or deliver up' to a liquidator accounting records documenting the affairs of the company as is required by section 386 of the Companies Act 2006. According to Department for Business' figures, 'Crown debt' misconduct was cited in 52 per cent of disqualification for unfitness cases in $2012^{89}$ with 'accounting misconduct' cited as the second most common form of unfit conduct in 17 per cent of cases. Matters of misconduct that are targeted by existing civil recovery powers, by contrast were cited less frequently. Company directors causing or permitting a

\footnotetext{
${ }^{87}$ Williams, 'What can we Expect', n 4, 82.

${ }^{88}$ See eg Re Sevenoaks Stationers (Retail) Ltd [1991] Ch 164.

${ }^{89}$ Insolvency Service, Annual Report and Accounts 2011-2012 (London: 2012), table 16, available at http://webarchive.nationalarchives.gov.uk/20121212135622/http://www.bis.gov.uk/assets/insolvency/d ocs/publication-pdfs/ar2011-2012.pdf (last accessed 6 November 2014).
} 
company to enter into 'transactions to the detriment of creditors', which includes, for example, preference or undervalue transactions, was cited in 13 per cent of cases whilst 'trading whilst insolvent' to the detriment of creditors was cited in just 0.005 per cent of cases (seven instances out of 1,215 disqualifications). ${ }^{90}$

No doubt mindful that these patterns of misconduct make the Crown the likely principal beneficiary of civil recovery in disqualification, the Department for Business has stated it does not intend to use the new powers to seek recovery for Crown agencies, but would instead target cases where director misconduct causes loss to non-Crown creditors ${ }^{91}$. In principle, of course, this is welcome. If the Crown were to take the lion's share of any new civil recovery, this would leave the department open to the charge that the new powers were doing little to benefit ordinary creditors. On the other hand, however, removing Crown debt from the ambit of civil recovery only serves to emphasise the fact that a relatively small number of disqualification cases relate to misconduct that is targeted by existing civil recovery powers, which, of course, are the cases where director misconduct causes the greatest loss to creditors. This is all the more so because 'accounting records' cases, the most numerous form of unfit conduct after Crown Debt matters, are poorly suited to civil recovery.

\section{The Limits of Civil Recovery: Accounting Misconduct}

Insolvency Service figures show that directors' failure to 'maintain, preserve or deliver up to a liquidator' accounting records documenting the affairs of the company was cited as a matter of unfit conduct in, on average, 20 per cent of unfit conduct cases between 2008-2012. ${ }^{92}$ This fits broadly with the results of a more detailed study of disqualifications undertaking cases in $2008^{93}$ which found record cases to account for 27 per cent of disqualifications.

The duty of company officers to maintain internal accounts and records serves as a safeguard for shareholders and creditors of companies in so much as it seeks to ensure that directors have adequate information to hand by which to judge the health of the company and plan future decisions. ${ }^{94}$ Disqualification cases have emphasised the importance of directors maintaining adequate records in the particular context of trading with limited liability ${ }^{95}$ and that such accounts are delivered to insolvency practitioners. ${ }^{96}$

Few would doubt the importance of directors maintaining and 'delivering up' such records to a liquidator and deny that a failure to do so may well be evidence of 'unfit conduct'. However, whilst such cases may be good evidence of unfitness, they are a poor basis for civil recovery as it is often difficult to identify clear losses to creditors from a failure to maintain, but particularly, a failure to 'preserve or deliver to a liquidator', accounting records.

\footnotetext{
90 ibid.

${ }^{91}$ Department for Business, Innovation and Skills, Small Business, Enterprise and Employment Bill: giving the Court and Secretary of State a Power to Make a Compensation Award against A Directors (BIS/14/932), n 21.

${ }_{92}$ Insolvency Service, Annual Report and Accounts 2011-2012, 89.

${ }^{93}$ Williams, 'Disqualification Undertakings', n 14.

${ }^{94}$ See eg Secretary of State for Trade and Industry $v$ Arif [1996] BCC 586.

${ }^{95}$ See eg Re Rolus Properties Ltd (1988) 4 BCC 446, 447; Re Swift 736 Ltd [1993] BCC 312, 315 :

"Those who take advantage of limited liability must conduct their companies with due regard to the ordinary standards of commercial morality. They must also be punctilious in observing the safeguards laid down by Parliament for the benefit of others who have dealings with their companies. They must maintain proper books of account and prepare annual accounts; they must file their accounts and returns promptly; they must fully and frankly disclose information about deficiencies in accordance with the statutory provisions."

${ }^{96}$ Secretary of State for Trade and Industry $v$ Arif, $\mathrm{n} 94$.
} 
The detailed 2008 study of undertaking cases uncovered 109 accounting records cases in a sample of 397 cases. Narrowing analysis of the data set to directors disqualified for over 6 years (ie those cases targeted in potential civil recovery cases), 'accounting records misconduct' was cited in 63 cases. In all but a handful of those 63 cases the statements of misconduct attached to the disqualification undertaking stated that insolvency practitioners had been unable to account for financial transactions entered into by the company because of the failure to deliver accounting records, but made no specific allegation of improper use of corporate funds.

The overwhelming majority of cases citing accounting records misconduct did not, therefore, cite any evidence of direct loss to creditors from the misconduct. Some cases did contain an inference of misuse of company funds harming creditors as a result of the inability to explain company transactions ${ }^{97}$, but few, as noted above, made such a specific allegation. A typical example is the citation of unfit conduct relating to a director of Ralston Group Ltd who was disqualified for a period of six years. Accounting records misconduct was the only matter of unfit conduct cited in the case and the citation of unfit conduct read as follows:

"[The director] failed to maintain and/or preserve adequate accounting records and failed to deliver up adequate accounting records for the period of 1 January 2006 to 26 September 2006 ([t]he latter date being the last transaction of over $£ 1000$ shown on Ralston Group Ltd's bank account) and as a consequence [...] it has not been possible to satisfactorily explain income of $82,979.02$ and expenditure of $£ 129,765.64$ shown on Ralston's bank account and corporate card statement[.] [Further, the disqualified individual] has failed to provide a satisfactory account of the receipts totalling $£ 82,979.02$ and expenditure totalling [£129,765.64] referred to above" ${ }^{\text {"98 }}$

In so much therefore as the majority of 'accounting records' cases offer no clear evidence of loss to creditors, this has the effect of narrowing still further the likely extent to which we can expect civil recovery in disqualification to yield significant new compensation for creditors. What is more, analysis of the data set gathered from the author's study suggests that bankrupt disqualified directors are significantly less likely than the norm to have been disqualified for acts such as accounting misconduct but are more likely to have been disqualified for misconduct that is readily identifiable with creditor loss.

\section{Misconduct in 'Bankruptcy' Cases}

Of the 90 individuals declared bankrupt between corporate insolvency and up to 3.5 years after disqualification in the study group, 28 individuals, or 31 per cent of the 90 , were disqualified on the basis that they had caused or permitted 'transactions to the detriment of creditors'. Typically these cases concerned corporate assets being diverted to directors personally or to associated individuals and companies in the period immediately before insolvency for little or no value. A further seven directors were disqualified on the basis of a specific allegation of having caused or permitted a 'transaction at a preference', a transaction at an undervalue or 'trading whilst insolvent'. In total over 38 per cent of the 90 cases cited misconduct that could characterised as causing direct financial loss to creditors and which could fall, broadly, under existing civil recovery powers.

\footnotetext{
${ }^{97}$ See eg citation of unfit conduct in disqualification undertaking relating to 'Iceni Cleaning and Maintenance Ltd', discussed in Williams, n 14, 5.54-5.55.

${ }^{98}$ Insolvency Service, Director disqualification outcomes database, record retrieved 22 July 2008.

Records of unfit conduct in disqualification cases are kept on the database for a period of three months. The database, with details of recent disqualifications, is available at: https://www.insolvencydirect.bis.gov.uk/iesdatabase/viewdirectorsummary-new.asp (last viewed 2 June 2015).
} 
In contrast just 14 per cent of cases across the whole study group of 456 disqualifications cited 'transactions to the detriment of creditors' as a matter of unfit conduct with a further 4 per cent citing a specific allegation of a preference or undervalue transaction or 'insolvent trading. ${ }^{99}$ Insolvency Service statistics from $2008-2009^{100}$ (the year that broadly corresponds to the study sample) ${ }^{101}$ show the same picture with just over 19 per cent (290/1517) of disqualifications during the year citing 'transactions to the detriment of creditors' or 'trading whilst insolvent' as a matter of misconduct.

Forms of misconduct that offer low prospects of civil recovery were, as one would expect from the analysis above, much less common in bankruptcy cases than they were across the whole sample of disqualification cases. Just 40 of 90 (44 per cent) of bankruptcy cases cited 'Crown debt misconduct' for example, compared to over $60 \%$ of cases across the whole sample group ${ }^{102}$ and just 17 of 90 (19 per cent) cases cited a failure to maintain, preserve or deliver to the liquidator records of company transactions, compared to 27 per cent of cases in the sample as a whole. ${ }^{103}$ In so much then as bankrupt individuals are more likely to have been involved in acts of misconduct that inflict clear and identifiable harm on creditors, then personal insolvency amongst disqualified individual may have higher impact on the prospects of civil recovery than appears even from analysis of overall rates of personal insolvency.

\section{F. DETERRANCE AND PROCESS}

The combined effect of high bankruptcy rates amongst individuals responsible for serious corporate misconduct and evidence that relatively few directors are disqualified for acts of misconduct that cause clearly identifiable financial harm to creditors, makes a powerful case that the net increase in financial redress for creditors from civil recovery in disqualification is likely to be limited. Indeed, high rates of personal insolvency suggest that civil recovery against delinquent directors is, by its nature, a remedy of limited scope.

However, whilst analysis of civil recovery powers naturally tends towards a focus on financial gain to creditors, it is important to look at advantages and disadvantages beyond monetary compensation. Civil recovery powers might, for example, have a beneficial deterrent effect on directors' misconduct and this is certainly a potential 'non-monetary' benefit of the particular reforms at hand. Any enhancement in the deterrent effect of the new powers though could only come from an increased likelihood of civil liability in disqualification as compared to the likelihood of sanction under existing rules. The principle (and practice) of civil liability for directors is long established in UK law and the new powers simply add a further mechanism by which it may come about. So, on rational deterrence assumptions, ${ }^{104}$ we could only expect to see an increase in deterrence from the new powers to the extent that they make civil recovery more likely that it was before. On this the evidence is,

\footnotetext{
${ }^{99}$ The data presented here includes analysis of both the undertaking and order cases in the sample group. Previously published analysis of director misconduct from this sample of cases presents analysis of only the 397 disqualification undertaking cases in the sample (see Williams, Disqualification Undertakings $\mathrm{n} \mathrm{14,} \mathrm{ch} \mathrm{5).} \mathrm{In} \mathrm{any} \mathrm{case,} \mathrm{the} \mathrm{addition} \mathrm{of} \mathrm{disqualification} \mathrm{orders} \mathrm{to} \mathrm{the} \mathrm{sample} \mathrm{made}$ relatively little difference, with only a slight increase in the incidence of 'transactions to the detriment of creditors in the whole sample of 456 undertakings and orders, as compared to analysis of undertaking cases alone.

${ }^{100}$ Insolvency Service: Annual Report and Accounts (London: The Stationary Office, 2009), Table 16available at

https://www.gov.uk/government/uploads/system/uploads/attachment_data/file/250499/0623.pdf (last accessed 15th May 2014).

${ }^{101}$ See $\mathrm{n} 65$, and text thereto.

${ }^{102}$ The figures for the combined sample of 456 undertakings and orders on the study presented here reflect those previously presented for the 397 undertaking cases in the sample, see Williams, n 145.8 . 103 ibid.

${ }^{104}$ R. Baldwin ‘The New Punitive Regulation', (2004) 67 Modern Law Review 351, 371.
} 
as we have seen above, not encouraging, all the more so because the powers may alter patterns of recovery without necessarily increasing the overall amount of recovery to any great extent. So it is unlikely that the new powers would be transformative. Moreover, few directors are likely to be aware of the details of the new powers, any more than they are aware of the detail of existing provisions, ${ }^{105}$ and so we should not expect the deterrent effect of the new powers to extend too far beyond that of already established civil recovery rules.

Aside from the deterrent impact of the new rules, analysis of whether they offer a 'good' model of regulation should also not ignore the fairness of the rules proposed. Baldwin et al identify adherence to 'due process ${ }^{106}$ as a key pillar of 'good regulation' in the sense of the fairness, equality and consistency of treatment under regulatory rules. Of course, in any regulatory system, trade-offs may have to be made between strict adherence to 'due process' principles and effective attainment of regulatory objectives. Nonetheless, there will in every case be a level below which trading off principles of 'due process' against administrative convenience will call into question the desirability of the rule, and civil recovery in disqualification is no exception. Particular concern in this regard can be raised about the use of compensation undertakings as a means of imposing civil liability on directors.

The provisions relating to compensation undertakings in the new rules are intended to provide a route to dispose of 'uncontested' compensation cases where the Secretary of State and a disqualified individual are able to reach agreement on the question of compensation for creditors. Like disqualification undertakings, therefore, the system of compensation undertakings might offer benefits for both disqualified individuals and the Secretary of State.

In some cases of course, this may well be the case. But there are also substantial risks associated with the proposed new procedure. The new provisions of the CDDA provide, as we have seen, for binding compensation undertakings to come into force simply by substituting the court with the Secretary of State, as the authority with power to determine whether the criteria for imposing a compensation obligation. The new section $15 \mathrm{~A}(2)$ accordingly provides that the Secretary of State may accept the offer of a compensation undertaking where it appears to him that the conditions mentioned in section $15 \mathrm{~A}(3)$ for imposing compensation are met. This places the Secretary of State in the position of being both 'prosecutor' and 'judge'; 'prosecutor' because it is the Secretary of State who has statutory responsibility to investigate unfit conduct allegations and the sole power to bring compensation claims (s 15A(1)), and 'judge' because it is he who will decide (where an undertaking is offered) if the conditions in section $15 \mathrm{~A}(3)$ are met. The system mirrors almost exactly the position that exists in respect of general disqualification undertakings, where the Secretary of State (in reality the disqualification unit of the Insolvency Service) acts as investigator of directors' unfit conduct, 'prosecutor' through his role in applying for a disqualification order and arbiter of unfit conduct where a disqualification undertaking is offered. $^{107}$

There can be little doubt that the Secretary of State would be subject to rules of natural justice when exercising his administrative jurisdiction to determine the conditions in s.15(3) and deciding to accept the offer of a compensation undertaking. Neither can there be doubt about prima facie bias on the part of the Secretary of State. Predetermination ${ }^{108}$ of the s.15(3) conditions by the Secretary of State is a real likelihood given his role as prosecutor, but even

\footnotetext{
${ }^{105}$ See eg V Finch, Corporate Insolvency Law: Perspectives and Principles, (Cambridge: CUP, 2nd ed, 2009) 749. On limited deterrent impact of disqualification see further R Williams, 'Disqualifying Directors: A Remedy Worse than the disease?' (2007) 7 JCLS 213.

${ }^{106}$ Baldwin et al, n 37, 29.

${ }^{107}$ Company Directors disqualification Act 1986, ss 7(1), 7(2A). See also Williams, n 14, 3.5-3.10.

${ }^{108} R$ (Persimmon Homes Ltd) $v$ Vale of Glamorgan Council [2010] EWHC 535, see further P Craig, Administrative Law (London: Sweet and Maxwell, $7^{\text {th }}$ ed, 2012) 14-008.
} 
in the absence of that, it can hardly be said that a reasonable observer would not consider that a real possibility of bias existed under the statutory rules ${ }^{109}$.

In the context of the disqualification undertaking system, the dual role of the Secretary of State is defended on grounds that the undertaking process is consensual and the same may be said of the compensation undertaking rules. The Secretary of State will only exercise his quasi-judicial power to determine whether the conditions for making a compensation award in section $15 \mathrm{~A}(3)$ are met where a compensation undertaking is offered to him by a disqualified director. Consent to the authority of a biased adjudicator, freely given, ${ }^{110}$ has a firm grounding in administrative law as a potential remedy for strict adherence to principles of procedural fairness in quasi-judicial proceedings ${ }^{111}$, but there are difficulties with the consent argument in the context of disqualification proceedings and, by extension, compensation proceedings. It has long been recognised that many individuals subject to disqualification proceeding are unable to afford professional representation and may feel compelled by circumstances not to contest the case against them. ${ }^{112}$ This is compounded in general disqualification proceedings by the Secretary of State's practice of offering to waive costs against individuals who offer an early disqualification undertaking and concomitant promise to pursue costs against directors who do not ${ }^{113}$ and the possibility of oppression of respondent directors due to practice in respects of costs in undertaking was noted by the Trade and Industry Select Committee of the House of Commons prior to the enactment of the general undertaking rules. ${ }^{114}$ Against this backdrop there is a substantial risk that directors may feel similarly obliged to offer a compensation undertaking to the Secretary of State, where one is demanded, because they are unable to risk the additional cost burden that contesting a compensation application may bring. To be sure, a new section $15 \mathrm{C}$ of the CDDA will give the court power to vary or revoke the terms of a compensation undertaking upon an application from a disqualified person which, in ECHR terms at least, might offer a cure to bias through access to a court of 'full jurisdiction to deal with the case'. ${ }^{115}$ But this analysis rather misses the problem. Access to a court in principle is not the difficulty in undertaking cases, it is access in practice. True, it may be contended that cost is always an issue in legal proceedings and should not on its own establish a breach of due process rules. But in the context of regulation that specifically targets a group that, as the data presented above shows, are peculiarly likely to be subject to financial distress, ignoring the real potency of the costs issue appears somewhat pernicious.

From a broad, rights-based, perspective a failure to adhere to principles of fairness, equality and equal treatment might be seen to delegitimise a regulatory system simply by virtue of its failure to live up to expected norms of behaviour as between regulators and those whom they regulate. A more pragmatic, outcomes-based, perspective might, though, accord less weight to the simple failure to live up to such norms but be more concerned with the effects of such failures: 'unfair' regulation may simply be bad regulation in as much as a failure to treat the regulated class fairly may result in a greater likelihood of error in the regulatory system, decreasing its effectiveness. And the system for compensation undertakings, like that for disqualification undertakings, certainly does carry a risk of error where directors feel they have no choice but to agree to a compensation claim because of cost constraints. The Secretary of State is extremely poorly placed to determine the criteria in section $15 \mathrm{~A}(3)$ in a

\footnotetext{
109 ibid.

${ }^{110} R v$ Bow Street Magistrates Court ex parte Pinochet (No 2) [2000] 1 AC 119, 137.

${ }^{111}$ See eg H W R Wade and C F Forsyth, Administrative Law (Oxford: OUP, 11 ed, 2014), 398; Craig, Administrative Law, n 106, 14-011.

${ }^{112}$ See eg Lord Hoffmann, 'The Fourth Annual Lenard Stainer Lecture' (1997) 10 Company Lawyer 194, 197.

${ }^{113}$ Williams, Disqualification Undertakings, n 14, 3-20.

114 Trade and Industry Select Committee, 2nd Report, Draft Insolvency Bill (House of Commons Papers, Session 1998-1999, 112), para 42.

${ }^{115} R$ (Alconbury Developments Ltd) v Secretary of State for the Environment [2001] UKHL 23.
} 
sufficiently dispassionate manner to identify likely erroneous compensation claims given that he will have initiated the claim. Error in some cases is therefore all but inevitable.

Whether our concern is pragmatic or rights-based, however, the compensation powers replicate procedural failings in the broader disqualification undertakings system by failing to recognise the reality of disqualification proceedings for most directors. Indeed, the evidence presented earlier in this paper as to the heightened frequency of personal financial distress by disqualified directors highlights the importance that cost issues are likely to play in determining the behaviour of directors subject to proceedings under the Disqualification Act. Given this reality it would be far preferable for the legislation to provide for an independent reviewer of undertakings agreements to whom the Secretary of State and respondent directors could pass agreements for review and approval. To be sure, full procedural rights could still be compromised in such a process, to preserve the advantages of out-of-court disposal, but such a system would enhance the legitimacy and effectiveness of undertakings by removing the power of the Secretary of State to determine his own case in a context where the nature of the consent of respondent directors to such bias is uncertain.

\section{G. CONCLUSION}

High bankruptcy rates amongst directors implicated in serious corporate wrongdoing are likely to act as a significant constraint on the usefulness of civil liability rules to creditors of failed companies. This alone provides grounds for doubting the extent to which new powers of civil recovery in the CDDA are likely to meet their goals of enhancing redress for creditors of failed companies. Nonetheless, doubts are magnified by the lack of any compelling evidence as to the extent of the 'market failure' problem to which the new powers respond and the fact that relatively few disqualification cases concern the sort of misconduct against non-State creditors that is suited to civil recovery proceedings. The likely limited deterrent effect of the new powers, combined with concerns about the fairness of a key aspect underline further the weakness in regulatory strategy adopted in the new powers.

Granting the State a direct role in civil recovery proceedings against directors is a significant innovation in UK corporate insolvency law. It has the potential to significantly enhance the 'public' side of corporate insolvency proceedings and seems likely to have a significant impact on the approach of office holders to civil recovery proceedings in their management of the affairs of failed companies. But the weakness of the current reforms poses a clear danger of giving both office holders and creditors a false sense of security in the ability of the state to improve on outcomes achieved by existing rules. To be sure, there will be some successes, but they may simply come in place of successful recovery by office holders under existing recovery powers. Whatever the impact on patterns of recovery though, available evidence strongly indicates that civil recovery against delinquent directors, and civil recovery against disqualified directors in particular, are likely to be measures of limited usefulness. 